\title{
$\underset{\text { RSCAS } 200802}{\text { WUI Working Papers }}$
}

Altiero Spinelli and the Idea of the US Constitution as a Model for Europe: The Promises and Pitfalls of an Analogy 
EUROPEAN UNIVERSITY INSTITUTE, FLORENCE

ROBERT SCHUMAN CENTRE FOR ADVANCED STUDIES

Altiero Spinelli and the Idea of the US Constitution as a Model for Europe:

The Promises and Pitfalls of an Analogy

ANDREW GLENCROSS

EUI Working Paper RSCAS 2008/02 
This text may be downloaded only for personal research purposes. Additional reproduction for other purposes, whether in hard copies or electronically, requires the consent of the author(s), editor(s).

Requests should be addressed directly to the author(s).

If cited or quoted, reference should be made to the full name of the author(s), editor(s), the title, the working paper, or other series, the year and the publisher.

The author(s)/editor(s) should inform the Robert Schuman Centre for Advanced Studies at the EUI if the paper will be published elsewhere and also take responsibility for any consequential obligation(s).

ISSN 1028-3625

(C) 2008 Andrew Glencross

Printed in Italy in January 2008

European University Institute

Badia Fiesolana

I - 50014 San Domenico di Fiesole (FI)

Italy

http://www.eui.eu/RSCAS/Publications/

http://cadmus.eui.eu 


\section{Robert Schuman Centre for Advanced Studies}

The Robert Schuman Centre for Advanced Studies (RSCAS), directed by Stefano Bartolini since September 2006, is home to a large post-doctoral programme. Created in 1992, it aims to develop inter-disciplinary and comparative research and to promote work on the major issues facing the process of integration and European society.

The Centre hosts major research programmes and projects, and a range of working groups and ad hoc initiatives. The research agenda is organised around a set of core themes and is continuously evolving, reflecting the changing agenda of European integration and the expanding membership of the European Union.

Details of this and the other research of the Centre can be found on: www.eui.eu/RSCAS/Research/

Research publications take the form of Working Papers, Policy Papers, Distinguished Lectures and books. Most of these are also available on the RSCAS website: www.eui.eu/RSCAS/Publications/

The EUI and the RSCAS are not responsible for the opinion expressed by the author(s). 



\begin{abstract}
Altiero Spinelli believed European integration needed to draw inspiration from the US constitutional founding. This paper uses Spinelli's analogy to assess how useful it is to compare the predicament of European integration with US constitutional politics. The analysis contrasts how Europe and the US experienced problems of sovereignty clashes and institutionalizing democratic accountability. It reveals both how Spinelli exaggerated the extent to which the US Constitution established and delimited federal political authority once and for all as well the way in which, despite its functionalist non-constitutional origins, the EU has experienced its own brand of constitutional politics. The analogy is thus most useful in showing how both polities faced a similar tension between the process of constitutionalism, restraining unit sovereignty, and the institutionalization of popular sovereignty at the federal level. Furthermore, the contrast with the US suggests the EU is mired in a Calhounian situation, reminiscent of the antebellum republic, where federal constitutionalism is only indirectly supported by popular sovereignty. Consequently, it seems that bolstering federal constitutionalism requires a better linkage between the exercise of popular sovereignty at the national level and EU constitutional reform.
\end{abstract}

\title{
Keywords
}

Spinelli, EU constitutionalism, US Constitution, constitutional politics, popular sovereignty 



\section{Introduction}

In an 1957 essay entitled 'Il modello costituzionale americano e i tentavi di unità europea', Altiero Spinelli explored the validity of seeking inspiration from the US constitutional experience to devise the institutional architecture of European integration. Spinelli's essay was entirely in keeping with the twin axes of his lifelong practical and theoretical engagement with the project of European unity: it criticized the functionalist approach and advocated instead the need for a constitutional foundation for the pooling of sovereignty (Spinelli, 1989; Pistone, 1990). This paper uses Spinelli's essay as a point of departure for assessing the promises and pitfalls of the analogy he developed - one which is proving increasingly popular today (McKay, 2001; Nicolaïdis and Howse, 2001; Kelemen, 2004; Fabbrini, 2005a; Menon and Schain, 2006) - between the predicament of European integration and the constitutional politics of the US republic. In particular, the analysis focuses on the fundamentally interrelated issues of the organization of sovereignty and arrangements for ensuring democratic accountability.

The paper is structured as follows. The first section reviews Spinelli's attempt to draw lessons for European integration from the US constitutional founding. The second section scrutinizes Spinelli's key assumption that by choosing the constitutional avenue the US founding resolved the twofold problem of sovereignty clashes and democratic restraint of federal power. Section three reviews the EU experience of handling problems of sovereignty and democracy within a functionalist framework that Spinelli saw as the dreaded rival to a constitutional model based on the US experience. Finally, the fourth section explores what can be learnt from the transatlantic comparison, especially with reference to the various projects of EU democratization currently debated in the context of the enduring constitutional crisis sparked off by the defunct Constitutional Treaty. A concluding section closes the argument.

\section{Spinelli's Contrast between the Constitutional and the Functionalist Model of European Unity: Two Perspectives on the US Analogy}

Spinelli believed that functionalists and federalists were at odds in their appreciation of the validity of drawing on the US constitutional model when designing the institutions of European integration. According to this interpretation, functionalists rejected the pertinence of the analogy because the various conditions for a viable federal constitution (similar economic development, linguistic and cultural homogeneity, and little experience as independent sovereign units) were not present in the European case (Spinelli, 1993: 262-4). Nonetheless, the analogy remained germane from a longerterm functionalist perspective: 'federation had to be the endpoint and not the starting point of the process of [European] unification, unlike what occurred in the United States' (ibid. 265). In this sense the ultimate goal of functionalism was beholden to the US model even if the process of reaching this constitutional conclusion was to take a different course.

Conversely, European federalists, like Spinelli himself of course, sought to draw immediate inspiration from the US federal model in their quest to reorganize political authority in Europe. For Spinelli this claim was partly based on a historical argument that functionalists were deceived in thinking that the constitutional success of the US federal experiment was due to propitious historical circumstances. This auspicious interpretation of the origins of the US Constitution was, he pointed out, belied by the far from sanguine assessments of the future of American unity voiced by many commentators in the period of the Philadelphia Convention (ibid. 266-7). Moreover, functionalists conveniently overlooked the fact that US federalism had a highly credible rival form of political organization, the confederal model, which in the debates over the proposed constitution was often taken to be the appropriate arrangement of sovereignty for the former British colonies (Storing, 1985). 
As Spinelli rightly recalled, in the 1780s many political actors 'dared not think it possible to go beyond the model of a confederation of sovereign states’ (Spinelli, 1993: 267).

Spinelli, however, did not simply seek to refute the Whig-like interpretation of the supposed 'preconditions' for a successful federal constitution. His fondness for the US analogy was also linked to the conceptual premise that the US Constitution was designed as a solution to problems of sovereignty and democracy identical to those facing European states in the post-war context (Spinelli, 1993: 2678). It was precisely this commonality that Spinelli identified as the fundamental reason why Europe had much to learn from the US model of federal constitutionalism. Thus he remarked that 'the supranational unification of certain specific aspects of public authority cannot escape the logic of the US system, because they both belong to the same logic of the construction of political authority' (ibid., 269-70). Hence the importance of the US analogy for the European case lies in the fact that they both faced the 'same problem of the establishment of political authority and the specification of its limits' (ibid., 270).

Spinelli thus characterized the US federal constitution of 1789 as a system for creating a sovereign power 'whose capacity to decide and execute would be independent of the goodwill of the single states, because these latter would ordinarily be competent to administer public affairs only as they pertained to their particular community' (ibid., 269). Identical to the US constitutional doctrine of federalism as a system of 'dual federalism' (Derthick, 2001: 45), in Spinelli’s essay this interpretation implied that:

state and federation would each have in common, on the one hand, the citizen, belonging equally to the state and the federation, obliged to obey the laws of both and owing taxes to both, and, on the other hand, state and federation would each have a common duty to obey a federal court whose task was to uphold the federal pact, deciding whether one or the other power had acted beyond its competences and invaded those of the other. (Spinelli, 1993: 269).

Furthermore, beyond the problem of sovereignty, the constitution was also intended to conserve democratic accountability at each level by 'guaranteeing both the various elements of the separation of powers and the control of the governed over the governing' (ibid.). European federalists, in their struggle against the functionalist logic of integration, thus confronted the same constitutional predicament as that of the US founding fathers, namely: 'what kind of European political authority should exercise what competences and how should these be established?' (ibid., 270).

Spinelli thus used the US experience to advocate the need for a similar constitutional, rather than functionalist, blueprint for European integration. The argument, therefore, is fully in keeping with his strategy to convoke a European constituent assembly modelled on the Philadelphia Convention to produce such a constitutional outcome (Pistone, 1990). However, this paper does not seek to question the validity of the constituent assembly approach to the problem of European integration, which in any case has already attracted serious academic interest largely thanks to Europe's own attempt to mimic Philadelphia, the Convention on the Future of Europe (Loughlin and Walker, 2007). Rather, I propose to examine the central supposition underlying Spinelli's general argument about why the US constitutional model is so relevant for the European integration project. Namely, the claim that the US Constitution, which has survived to become the oldest republican founding document in existence, from the outset resolved certain crucial problems of sovereignty and democracy. It is this supposition that needs to be scrutinized in order to assess exactly the merits and demerits of making an analogy with the US founding when discussing the reorganization of political authority in Europe. It is hoped that such an analysis will nuance Spinelli's argument about what European integration can learn from the US model, so as to turn the analogy into less of a nostrum and more of a tool for critical reflection on the nature of constitutional issues in the EU. 


\section{To what Extent did the US Constitution Resolve Issues of State Sovereignty and Popular Sovereignty?}

The US constitutional founding did not specify a single locus of sovereignty. In this way, the constitution symbolised the retention of the Tudor principle of a government of 'separated institutions sharing powers' (Huntington, 1966: 393), which the colonists had fought to preserve in the face of the new-fangled British doctrine of parliamentary sovereignty. Dual federalism, the sharing of powers between state and federal level, consists of four features:

the national government is one of enumerated powers only; the purposes which it may constitutionally promote are few; within their respective spheres the two centres of government are "sovereign" and hence "equal"; the relation of the two centres to each other is one of tension rather than collaboration. (Derthick, 2001: 45).

The establishment of two sovereign centres of government in tension with each other meant that from the outset the Supreme Court was expected to be the arbiter in the predicted struggles over jurisdictional competence. Certainly this was the intention of Publius, who wrote in Federalist 22 that 'all nations have found it necessary to establish one court paramount to the rest, possessing a general superintendence, and authorized to settle and declare in the last resort a uniform rule of civil justice' (Hamilton, Madison and Jay, 2003: 104). This explains why Spinelli felt inspired by what he saw as the US constitutional model's institutional ability to settle issues of competing sovereignty claims by establishing a pellucid competence catalogue (albeit with the possibility of constitutional amendment) overseen by a supreme tribunal.

However, the record of clashing sovereignty claims after the US Constitution came into force in 1789 is far more complex, involving as well as affecting the exercise of popular sovereignty. Simply put, US political development in the antebellum period was punctuated by a series of clashes that called into question the stability of dual federalism and the ability of the Supreme Court to resolve these federal crises. Indeed, the establishment of a federal political authority and the organization of a complex 'compound' (ibid., pp. 253-4; cf. Fabbrini, 2001, 2005b) method of checking the exercise of this power heralded the birth of US constitutional politics (Ackerman, 1991, 1998). Pace Spinelli, both the political authority of the federal government and the democratic means for checking its action were subject to repeated contestation.

Although this is an abstruse story, I propose to illustrate this process of contesting federal sovereignty and arguing over popular sovereignty with only a selected few examples. The chosen constitutional disputes represent clashes between different conceptions of the proper nature of the federal system, chiefly the distribution of competences and the institutionalization of popular sovereignty within the federal architecture. In this sense they are a continuation of the original federalist debates over the constitution (Storing, 1985), especially since the abandonment of the Virginia plan and its proposed federal veto over state legislation left the relationship between units and union highly uncertain (Robertson, 2005: 95-8). The analysis will thus focus largely on the antebellum period since this was the period in which the experiment in dual sovereignty unraveled as advocates of state sovereignty clashed with nationalists over the co-existence of popular sovereignty at two levels.

The clearest examples of early struggles to define the nature of the US federal system are the nullification crises of 1798 and 1832 (McDonald: 2000). The former concerned the so-called Alien and Sedition Acts' restriction of civil liberties, whilst the latter was the result of South Carolina's hostility to the imposition of tariffs on imports of manufactured goods. In the first case, two states challenged the federal government's constitutional right both to claim jurisdiction over resident aliens in a state and to restrict the liberty of the press. Under the constitution of 1789 no specific power had been granted to the federal government concerning aliens except with regards laws of naturalization, whilst the bill of rights specifically protected free speech. In these circumstances the state legislatures of Kentucky and Virginia upheld the right not to comply with these federal laws, claiming in effect a veto over this unconstitutional extension of federal sovereignty, and publicized their struggle to gain 
the support of other states (ibid.: 43). In other words, when confronted with federal legislation they deemed unconstitutional, Kentucky and Virginia found the existing system for checking federal authority wanting and thus sought a new mechanism for stymieing the exercise of federal power. Thus, less than a decade after the entry into force of the constitution, the mechanism for maintaining the distribution of sovereignty within the dual federal arrangement was already called into question.

A near-identical situation arose in 1832 over Congress' protectionist tariff on manufactured imports, which South Carolina thought unfairly targeted plantation states. The tariff crisis also marked a turning point in the antebellum period by sparking a full-blown theoretical reflection on the connection between state sovereignty and popular sovereignty within the union. South Carolina's assertion of the right to judge the constitutional limits of federal government provoked a fervent debate over whether the Union was a treaty-like compact between sovereign states or the constitution of a single people.

Opponents of South Carolina's “compact” reading of the American union pointed to the constitution's ratification by the people in separate state conventions to undermine this claim that states could unilaterally defy the federal government. ${ }^{1}$ Hence Andrew Jackson, in his presidential proclamation on the tariff crisis, argued that the use of state conventions 'show [the constitution] to be a government in which the people of all the states collectively are represented' (Elliot, 1836, vol. 4: 589). Moreover, given crucial changes affecting the presidential election such as the easing of property requirements for voting (Swift, 1996: 99) and the introduction of direct election for presidential electors (Aldrich, 1995: 106), Jackson went so far as to argue that 'We are ONE PEOPLE in the choice of the President and Vice President ... The people, then, and not the States, are represented in the executive branch' (Elliot, 1836, vol. 4: 589).

It was precisely this Jacksonian innovation, whereby the presidency became a populist, national institution attenuating the original state- and elite-dominated election process - a shift further aided by the unexpected development and entrenchment of the national party system (Aldrich, 1995) - that led to John C. Calhoun's attempt to rethink the Union. Calhoun fundamentally 'thought that it was essential to revise republican theory and constitutional arrangements to fit these new circumstances' (Ford, 1994: 45). The American union had to adapt to a novel situation in which despite the size of the republic and the founders' constitutional devices the federal government was now potentially the instrument of a partisan majority, especially over the slavery question. In his mind, therefore, the federal system needed remodeling in order to simultaneously resolve the outstanding question of residual state sovereignty and the proper role of popular sovereignty within this framework (Forysth, 1981).

As well as delivering the definitive compact interpretation of the constitution, he developed not only a theory of 'concurrent majorities' as the cornerstone of federalism but also proposed a system of nullification as ex post device to counterbalance the development of a system of representation more centralized and majoritarian than at its origin (Calhoun, 1992; Ford, 1994). Both nullification and the notion of concurrent majorities were designed as means of using popular sovereignty at the state level to check federal authority (Forsyth, 1981). Reading the constitution as a compact between states meant that popular sovereignty ought to be exercised at the state rather than federal level.

The Union's victory in the Civil War was the death knell for Calhoun's compact reading of the constitution and with it the doctrines of nullification and secession: the union was the government of a single sovereign people. By virtue of its victory, the post-war Union thus acquired a new settlement as far as competency over competences was concerned. States lost their claim to be able to withdraw

1 This line of reasoning was most famously expressed by Chief Justice John Marshall, in McCulloch v. Maryland (1819): 'from these conventions the Constitution derives its whole authority. The government proceeds directly from the people ... The assent of the States in their sovereign capacity is implied in calling a convention, and thus submitting that instrument to the people. But the people were at perfect liberty to accept or reject it; and their act was final. It required not the affirmance, and could not be negatived, by the State governments. The constitution, when thus adopted, was of complete obligation and bound the states' (Baker, 1974: 595). 
from the Union, nullify laws or unilaterally question the constitutionality of its acts. Under this new understanding of the constitution, therefore, popular sovereignty at the state level could not be used to unilaterally contest federal authority. However, problems of democratic accountability at the federal level were only just beginning to emerge. Even if the principle of locating popular sovereignty at the federal level had been won there remained three unanswered questions. Firstly, who was a member of the sovereign body of citizens, secondly how would it exercise its will and, thirdly, what competences could the federal government claim as a result of a popular mandate?

These problems were already apparent during Reconstruction with the stillborn civil rights movement leading to the fourteenth and fifteenth amendments that tried to emancipate former slaves (Foner, 1988). It was the Compromise of 1877, which secured the Southern Democrats' support for Republican candidate Hayes in the Presidential election, that effectively sanctioned the federal government's willingness to turn a blind eye to civil rights abuses in the former slave states, an arrangement that was to last until the 1950s (ibid.). Yet civil rights - the first unresolved question, that of inclusion within the sovereign people - was only one aspect of the contestation over popular sovereignty at the federal level in the post bellum republic.

Before the second wave of civil rights activism, the federal system underwent two further defining moments in the struggle over the nature of popular sovereignty within the federal framework: the Progressive era, which led to the constitutional amendment providing for the direct election of senators in 1913, and Roosevelt's New Deal. The move from indirect to direct representation in the Senate and the contemporaneous amendment establishing a federal income tax further underlined the fact that the union was based on a single sovereign people with an unmediated connection between the individual and the federal government. Progressivism thus resolved the second question of how the sovereign body of citizens would exercise its will. It did this by ensuring that popular sovereignty at the federal level would be based on the direct participation of citizens, who would also have a greater influence over the national parties thanks to the innovation of the primaries.

Furthermore, these two moments, Progressivism and the New Deal, were in a sense complementary. Whilst the progressive movement aimed to shake-up corrupt machine politics and aloof party leaders for the sake of more responsive federal government (Hofstadter, 1955), the New Deal conflict over the role of the judiciary was designed to prevent Supreme Court justices fettering the will of a popularly elected government (Ackerman, 1998). Hence the evolving nature of popular sovereignty at the federal level led to a clash with the judicial power - the third unresolved problem. This was because the Supreme Court, for a variety of reasons, remained wedded to a static concept of US federalism - what Lowi (2006) has called a minimalist, 'patronage state' - and was prepared to uphold this even in the face of a popular mandate for greater federal intervention in the economic sphere. As a result of Roosevelt's threat to pack the Court with pliable appointees (Kyvig, 1989), federal competences expanded greatly, just as they also did during the later civil rights period. In this way, the twentieth-century democratization of the federal republic gave rise to new clashes over the proper scope of federal government even after the Civil War had rendered unilateral attempts to assert state sovereignty unthinkable.

This section sketched the manifold ways in which the US Constitution was, over the course of more than one hundred and fifty years, beset by the twofold problem of state sovereignty and popular sovereignty. These conflicts lasted even in the face of the continuous rise of national sentiment as a result of participation in war, the expanding frontier and the birth of American literary and cultural production. Contrary to Spinelli's argument, therefore, the constitution itself did not mark the establishment of political authority and the specification of its limits once and for all. Rather, the basic rules of the game of politics were challenged repeatedly until state sovereignty withered after the Civil War, and once the New Deal - as well as the later Civil Rights movement - affirmed that federal government could use its sovereignty claim to carry out a popular mandate of competence expansion. It is now necessary to examine how Europe, which Spinelli understood to have embarked on a functionalist alternative to a constitutional federal system, has fared in handling analogous problems. 


\section{The European Experience of Sovereignty Clashes and the Problematic Institutionalization of Popular Sovereignty}

The intention here is not to dispute Spinelli's claim that the functionalist avenue of integration - at least as far as he understood the concept - was pursued by contrast with the constitutional approach. Instead, the paper explores what, if anything, this non-constitutional method entailed for clashes of state sovereignty and the institutionalization of popular sovereignty within the architecture of integration. Again, this is a highly convoluted tale since the integration process has been addled by conflicts over competences and the problem of defining the proper relationship between member states and the EU for the purposes of democratically checking the latter. Hence the analysis focuses on the difficulties that have arisen when both these issues of state sovereignty and popular sovereignty have fused in the politics of integration.

In fact, the politics of integration have in many ways been transformed into constitutional politics tout court thanks to the actions of the European Court of Justice (Weiler, 1999). This process of surreptitious - at least from some of the member states' perspective - constitutionalisation is the result of the landmark supremacy and direct effect rulings. It is further illustrated by the Court's willingness to use the language of fundamental rights well before the Charter of Fundamental Rights was conceived. ${ }^{2}$ Spinelli, in his attack on the functionalist nature of the EEC regime, did not anticipate how the Court's use of the preliminary reference procedure combined with the prerogative to interpret provisions of the treaty would be turned against member state sovereignty. He was not alone, since the member states expected the court to deal with disputes arising under Articles 169 and 170, which enabled the Commission or a member state respectively to bring a suit for a state's failure to fulfill treaty obligations (Moravcsik, 1998: 155). However, for present purposes, constitutionalisation via law is most important for the way in which it both changed member state expectations about the nature of integration and has remained only indirectly linked with popular sovereignty.

By winning the struggle over the supremacy of European treaties and legislation and their ability to create judiciable rights for individuals against member state - neither of which existed under the ECSC treaty - the Court clearly distinguished the EEC from an ordinary international organization. In fact, the authors of The Federalist would have immediately recognized the import of these changes since Publius identified 'the characteristic difference between a league and a government' as precisely the ability to 'extend the authority of the Union to the persons of the citizens' (Hamilton, Madison and Jay, 2003: 68). Member states have reacted accordingly, at least when new European policies and competences were tabled. First of all, recalcitrant countries have successfully obtained opt-outs from certain policies (notably the Euro, in the case of Denmark, Sweden and the UK) ${ }^{3}$ as well as specific treaty provisions shielding them from certain obligations (Denmark and Malta can maintain restrictions on non-resident home ownership, the UK is currently seeking opt-outs from being bound to the Charter of Fundamental Rights). Moreover, at Maastricht, the member states deliberately designed the pillar system so as to insulate these new areas of putative EU competence from the process of constitutionalisation through law.

In restricting the jurisdiction of the ECJ over second and third pillar policy areas, the states ensured that legal acts bind states in what Publius called their 'corporate or collective capacities' (ibid. 67) and do not create rights for individuals. Even though the EU Constitution proposed the abolition of the pillar system, the circumscription of ECJ jurisdiction was to be maintained (Articles III-376 and III377). A precedent for such a move can be found in the Amsterdam Treaty, where elements of the

2 For instance, Case 29/69 Stauder [1969] ECR 419, para. 7, Case 11/70 Internationale Handelsgesellschaft [1970] ECR 1125, para. 4.

3 The effectiveness of opting out is by no means guaranteed. For instance, Denmark's Amsterdam opt-out from Title IV provisions (visas, asylum, immigration and other policies related to free movement of persons) has in practice meant rather little since Denmark’s government has obtained 'intergovernmental parallel agreements associating Denmark with legislative measures under Title IV’ (Adler-Nissen, 2007:19). Ironically, the real difference is that by opting out Denmark has no influence on the rules it subsequently signs up to. 
former Justice and Home Affairs pillar were integrated into the first pillar although the procedures for legislating in this area did not follow orthodox community law (Hanf, 2001). The insistence on unanimity, member state co-power of initiative and reduced ECJ jurisdiction, has resulted in what has been described as the creation of a new hybrid, 'intergovernmentalised EC law' (ibid.: 17). Indeed, this move has given rise to a new inter-institutional sovereignty game as the Commission and Council clash over which legal regime relevant legislation should fall under (Hermann, 2007).

In all these instances, the justification for opting out of policies or restricting further constitutionalisation to the detriment of state sovereignty has ultimately revolved around respecting the democratic legitimacy of the nation-states in the EU system. The claim that popular sovereignty rightly pertains to the national level, which alone can sanction changes to the EU system, has thus been used in a Calhounian fashion to defend state sovereignty against the threat, whether by diplomatically-negotiated treaty reform or through jurisprudence, of overweening EU competence expansion. This claim is made most explicit when opt-outs have been specifically linked to concrete manifestations of popular sovereignty at the national level. For instance, in 2003, when Sweden held a referendum on the single currency even though when it joined the EU in 1995 no formal single currency opt-out had been secured.

The ultimate logic of this claim about the many sovereigns of the EU compact was reached with the decision to introduce an explicit right of withdrawal from the EU, as specified by Article 35 of the Reform Treaty. How important this provision will be in practice cannot be prophesied, but it does send a clear signal about the simultaneous - what Madison would have called "compound" - confederal (treaty-based) and federal (constitutionalised) character of the EU. Hence the dual character of political representation in the EU, whereby states and their citizens are represented as separate collective entities in the Council, whilst individual citizens are represented as a European whole by the Parliament and Commission (Kincaid, 1999). The central tension between these two principles of political representation has yet to be resolved.

Another good example of the complex interplay between defining the proper locus of popular sovereignty within the EU system and retaining residual member state competences can be seen in the disputes over the introduction of further QMV or increasing the purview of the European Parliament. Both these proposals were enshrined in the so-called Spinelli Draft Treaty Establishing the European Union (1984) and have since remained a core belief among euro-enthusiasts. In particular, as Fabbrini has noted, it is commonly assumed 'that the parliamentary model is the only viable solution to the question of the democratization of the EU' (2005b: 188). In an attenuated form, the parliamentarisation of the EU has occurred thanks to the introduction of co-decision; the use of QMV has also been extended. However, member states have likewise been adamantine in their unwillingness to countenance either the wholesale generalization of QMV or the extension of codecision to all policy fields, thereby perpetuating the antagonistic co-existence between confederal (intergovernmental) and federal (supranational) principles (Majone, 2005). Constitutionalism via the construction of supranational legal has thus not been matched by the establishment of a supranational form of popular sovereignty.

The retention of these confederal elements is justified precisely on the basis that EU policy-making can - in the absence of a single European popular sovereign - only be legitimized indirectly by the democratically-elected member state governments that participate in EU decision-making (Moravcsik, 2002; 2005). Another way of putting this is that the member states can collectively decide to delegate some of their sovereign authority for specific ends without thereby creating a superior locus of sovereignty to be made accountable to a single community (Majone, 2001). Nonetheless, constitutionalism implies the limitation of member state sovereignty, even in policy areas lacking formal EU competence, as in the recent case where the ECJ has frustrated Austrian attempts to restrict the number of German students entering its university system (Sharpf, 2007; Andersen and Glencross, 2007). In fact, the anticipated impact of unwanted constitutionalism is the motivating force behind current the UK's demand to opt out of the provisions of the Charter of Fundamental rights. 
Unsurprisingly, the opaque and ambiguous EU political system that has been established as a result of the awkward juxtaposition of constitutionalism and intergovernmentalism has provoked a critical re-examination of the norms of democracy itself. In particular, a serious attempt has been made to shift the notion of democratic accountability away from the paradigm of popular sovereignty and representative government. This explains the use of terms such as 'pluralist democracy' (Coultrap, 1999), 'audit democracy' (Eriksen and Fossum, 2002) alongside the development of proxies for constituting democracy such as democratic governance (Zürn, 2000) or 'limited democratic politics' (Hix, forthcoming). None of these alternative conceptions of democracy, however, has proved capable of sundering the link with popular sovereignty, which explains why the EU is still beset by democratic deficit anxiety.

The newest element in this tussle over the nature of state sovereignty and the exercise of popular sovereignty within the EU concerns the use of referendums to ratify treaty reform in certain member states. Referendums were intended to act as improved - compared with indirect legitimacy via national governments - legitimating devices to connect the multiple popular sovereigns of the EU with the project of deeper integration. Ironically, the referendum experience has instead revealed the glaring gap, in many member states, between political elites and citizens over integration issues ${ }^{4}$ thereby leading some to question the very legitimacy of holding referendums on treaty matters.

Here again the issue of popular sovereignty intersects with the problem of member states' competence claims since the denial of a state's right to hold a referendum is obviously an abrogation of its competences. Although referendums on treaty matters have existed since the 1970s (a decade in which France voted on enlargement and the UK chose to remain in the EEC) and have even failed in the recent past (in Denmark in 1992, in Ireland in 2001) it is the scuppering of the EU Constitution by popular votes in France and the Netherlands that has led to a thorough questioning of the appropriateness of this method of ratification. On the one hand, some have used this crisis to denounce any resort to the referendum device for treaty reform (Dehousse, 2006), whilst others have looked to the Swiss experience to recommend the introduction of Europe-wide referendums with a double qualified majority of citizens and states (Trechsel, 2005; Auer, 2007). Thus the former approach calls for the end of national referendums on EU treaties whereas the latter approves their use so long as they cannot become tantamount to national vetoes. Only Schmitter (2000: 120-25) has dared to suggest that simultaneous national treaty referendums could be used creatively to determine the contours of EU constitutionalism by allowing certain member states to plump for greater integration more while leaving others in a looser confederative association. Grasping the inherent connection between popular sovereignty and competence issues, Schmitter seeks to use the former to settle the latter - a novel method of escaping the unanimity trap for EU treaty reform.

The referendum issue, therefore, has merely complicated the twofold problem of sovereignty clashes and the institutionalization of popular sovereignty. In terms of state competences, the establishment of EU supremacy and direct effect has had an unequivocal impact on determining the scope of member state sovereignty. Yet within the constitutional politics of the EU this settlement remains the exception, ${ }^{5}$ whilst the problem of the nature and exercise of popular sovereignty has become more vexing. In the light of this analysis, the next section reviews the appropriateness of drawing comparisons with the US and comments on the validity of Spinelli's own transatlantic analogy.

4 This gap is further illustrated by the rise of anti-EU parties and their success in certain member states in EP elections, which suggests that conventional domestic parties have shirked politicizing integration (Mair, 2007).

5 Subsidiarity, the principle supposed to settle competence issues has proven a stillborn mechanism for deciding the level at which competences are to be exercised. 


\section{Promises and Pitfalls of the EU/US Analogy}

Bringing together the analysis of both political systems from the previous two sections reveals that some of Spinelli's implicit assumptions about why the US Constitution could serve as a model for European integration were misguided. First of all, it should be evident that he overstated the importance of the US constitutional foundation when it came to 'the establishment of political authority and the specification of its limits' (Spinelli, 1993: 270). The course of political development charted above only confirms Lowi's pithy remark that 'the United States of 1789 was neither united nor a state' (2006: 102). The authority of the US government and the means for limiting its functioning were subject to repeated contestation in ways not imagined by Spinelli, for whom the US constitution could be resumed to the states' and federal government's 'common duty to obey a federal court whose task was to uphold the federal pact' (Spinelli, 1993: 269). When this contestation reached its paroxysm, the US experienced a series of new constitutional foundations, the Civil War, the New Deal and Civil Rights (Ackerman, 1991, 1998).

Moreover, the constitutional road not taken by Europe appears not to have made a significant difference to the nature of the debates over state sovereignty and the institutionalization of popular sovereignty when compared to the US experience. The analysis has shown that despite its so-called functional origins, the integration process has nonetheless been confronted by constitutional disputes analogous to those occurring in the course of US political development. Functionalism was thus no bar to the rise of constitutional politics in Europe. Hence the value of the analogy seems to reside neither in taking the US Constitution as a template for immediate constitutional change nor as a blueprint for eventual full EU constitutionalisation. Rather, the comparison is most useful in that it reveals the shared struggles to institutionalize popular sovereignty as a way of checking the limits of federal authority.

This was not something Spinelli seems to have considered troublesome in the US case as he simply stated that 'the Americans, like today's Europeans, desired to be ruled only by a democratic exercise of power' (Spinelli, 1993: 268). Yet as was shown above, the practice of popular sovereignty was a deeply divisive issue, giving rise to more than simply Calhoun's attempt to disprove the Jacksonian notion of the single sovereign people. Other features of this struggle include the decades of repression in the racist South over blacks' inclusion in the sovereign body, the Progressive movement's successful campaign for direct representation of citizens in the federal Senate and the New Deal clash between popular sovereignty and judicial authority. The result was that constitutionalism eventually came to be complemented by the institutionalization of popular sovereignty at the federal level.

The contrast with Europe on this point is significant. Direct representation was achieved in 1979 with the first elections to the EP, even if the EU is far from a fully parliamentary regime. This change in the institutional architecture further complicated the mixture of confederal and federal principles of representation by creating a body that can claim to represent the democratic will of all Europe's citizens. With the Commission and the Court already standing for the general European interest, it is the Council of Ministers and the European Council that represent the popular sovereignty and interests of the constituent units. The result is a mixed system of government in which the checks on the exercise of political authority at the EU level arise as a result of jurisdictional turf wars (Majone, 2006). Consequently, as Majone explains, the business of government is 'less in making policy for the entire polity than in questions of privileges and rights' (ibid., 127). Hence the EU system, Majone convincingly argues, ought not to mistaken for a straightforward separation of powers arrangement, based on the functional differentiation of government, as is often assumed in the comparative federalism literature (Kelemen, 2004; Kreppel, 2006)

The EU thus appears mired in a Calhounian situation - reminiscent of the antebellum republic and its constitutionalism only indirectly linked to popular sovereignty - in which the invidious question of competence attribution cannot be disentangled from the equally vexing one of institutionalizing democratic accountability via popular sovereignty. The acknowledged existence of multiple sovereigns within the EU system, as testified by the withdrawal mechanism as well as vetoes on treaty 
reform or enlargement, gives rise to a complex, antagonistic relationship between the exercise of popular sovereignty at the national level and European governance. So far, suggestions for the democratization of the EU have responded to this dual problematic of state sovereignty and popular sovereignty by seeking to attenuate the exercise of popular sovereignty at the national level, with few noticeable results. The mooted solution is either to shift towards a single European popular sovereign by parliamentarising the system and abolishing vetoes as well as unilateral national referendums on treaties, or else it is to devise a system of accountability that does not rely on the exercise of popular sovereignty.

Most recently, the EU clearly attempted to go down the path of a constituent assembly à la Philadelphia for the sake of producing a constitutional moment to serve as proof that EU citizens could constitute a single sovereign entity. The fact that this whole exercise was unraveled by the use of popular sovereignty at the national level does not mean that referendums ought to be considered a bogey figure for integration. Building on Schmitter's intuition, rather than declaiming their use, referendums could instead be seen as devices for defining the distribution of competences, decisionmaking procedures and even policies citizens of particular member states are willing to accept.

It is precisely in this context that the analogy with the US might become more pertinent from the perspective of the road not taken. Instead of focusing on the founding document, it seems appropriate to also examine the constitutional mechanisms Calhoun envisaged for making federal government more responsive to popular sovereignty exercised at the state level. To some extent this has already been done by Schmitter (2000: 84-106), who draws on the theory of concurrent majorities to propose a redesign of the voting system in the Council. However, Calhoun was also known as the theorist of the nullification device by which unilateral state nullification of federal legislation would trigger a convention of all the states to settle, by a three-quarters majority, whether a disputed law was constitutional (Calhoun, 1992). The nullification mechanism thus circumvented the Supreme Court deemed biased towards federal self-aggrandizement - for judging issues of constitutional authority and denied the federal government the right to interpret the limits of its own authority.

Instead of being simply a unit veto, therefore, nullification was a means to engender constitutional debate about competences between, on the one hand, states and their citizens and, on the other, the states and the federal government - a dialogue not otherwise possible and one which is also vital for the EU. In fact, seeking inspiration from this moment in US constitutional history appears especially germane given recent calls to increase the confederal element within the treaty system (Majone, 2006) and attempts to conceptualise the EU as a demoicracy explicitly founded on multiple sovereigns (Howse and Nicolaidis, 2001). The Reform Treaty's proposal to revise the subsidiarity mechanism by incorporating national parliaments into the procedure also suggests the relevance of exploring new devices for linking the exercise of popular sovereignty at the national level with EU governance.

\section{Conclusions}

The aim of this paper was to use Spinelli's essay on the US constitutional model as the starting point for a comparative analysis of America and Europe's respective constitutional experiences. America's constitutional foundation was undoubtedly one of the major sources of inspiration for Spinelli's eurofederalism. Although he did not seek to replicate its exact institutional framework or competence catalogue - he believed that every federal arrangement differed in this respect (Spinelli, 1993: 269) the idea of a fully-fledged constitutional foundation for Europe remained his political lode star.

Yet a closer inspection of his assumptions about the US constitutional model revealed the extent to which he incorrectly believed the constitution had foreclosed constitutional conflict. In particular, the twin issues of state sovereignty and the institutionalisation of popular sovereignty posed serious problems for the stability and functioning of the Union. Moreover, Spinelli's jeremiad against the functionalist nature of the EEC did not anticipate the fundamental constitutional transformation that occurred within the treaty framework. Thus, despite the lack of an original constitutional moment, 
European integration has in fact encountered constitutional conflicts over state sovereignty and popular sovereignty similar to those arising in the course of US political development.

On the one hand, therefore, the transatlantic analogy does not seem to warrant the hopes of Spinelli (and others) that a constitutional foundation will clarify and constrict the struggle over the rules of the game of integration politics. US political development clearly presents a different story, one where the units disputed the authority and the union for many decades due to their belief in keeping the locus of popular sovereignty at the state level. Even once the troublesome features of state sovereignty (secession and nullification) had been resolved in favour of the federal government, there remained unanswered questions crucial for democratic accountability: inclusion, representation and the federal competences that could be exercised with a popular mandate.

On the other hand, the travails of the US experience also suggest that the obsession with the succession of EU crises is perhaps overwrought (Kelemen, 2007). This is not to quibble with the serious problems of democratic legitimacy that have bedevilled the functioning of the EU. Indeed, the comparison with the US revealed just how difficult it was to settle the issue of competence alongside democratic accountability in a compound polity. In the EU context, the recent referendums on the EU Constitution have crystallised the issue of reconciling popular sovereignty at the national level with EU-wide treaty reform. These votes triggered a reaction against referendums on treaties or at least their unilateral use. However, the analogy with the US suggests that challenging state sovereignty directly - such as a peremptory curtailment of the member states' right to use referendums to deal with the political challenge of integration - is unlikely to pacify constitutional conflicts. Instead, European political elites will have to prove more willing to link popular sovereignty at the national level with EU constitutional reform - and more creative when doing so. Only in this way can EU constitutionalism be more directly linked to the exercise of popular sovereignty. 


\section{REFERENCES}

ACKERMAN, B. (1991) We the People: Foundations (Cambridge, MA: Belknap). (1998) We the People: Transformations (Cambridge, MA: Belknap).

ADLER-NISSEN, R. (2007) 'Organized Duplicity? When States Opt Out of the European Union’, paper presented at the SGIR Conference, Turin, 12-15 September.

ALDRICH, J. (1995) Why Parties? The Origin and Transformation of Political Parties in America (Chicago: University of Chicago Press).

ANDERSEN, S. and Glencross A. (2007) 'Pre-Empting the Court: Member State Expectations, Political Oversight and the Nexus of Law and Politics in the EU', paper presented at the European Union Studies Association Biennial Conference, Montreal, 17-21 May.

AUER, A. (2007) 'National Referendums in the Process of European Integration: Time for a Change', in Albi, A. and Ziller, J. (eds), The European Constitution and National Constitutions: Ratification and Beyond_(The Hague: Kluwer Law International), pp. 261-72.

BAKER, L. (1974) John Marshall: A Life in Law (New York: Macmillan).

CALHOUN, J. C. (1992) 'A Discourse on the Constitution and Government of the United States', in Lence, R. M. (ed.), Union and Liberty: The Political Philosophy of John C Calhoun (Indianapolis: Liberty Fund), pp. 79-284.

COULTRAP, J. (1999) 'From Parliamentarism to Pluralism: Models of Democrcacy and the European Union's “Democratic Deficit”', Journal of Theoretical Politics, 11 (1), pp. 107-35.

DEHOUSSE, R. (2006) 'The Unmaking of a Constitution: Lessons from the European Referenda', Constellations, 13 (2), pp. 151-64.

DERTHICK, M. (2001) Keeping the Compound Republic: Essays on Federalism (Washington D.C.: Brookings Insitution).

ELLIOT, J. (1836) Elliot’s Debates (Washington D.C.: Taylor \& Mauray).

ERIKSEN, E. and Fossum, J. (2002) 'Democracy through Strong Publics in the European Union?', Journal of Common Market Studies, 40 (3), pp. 401-24.

FABBRINI, S. (2001) 'The Puzzle of the Compound Republic: The US, EU and the Implications of Federalism', in Fabbrini, S. (ed.), Nation, Federalism and Democracy. The EU, Italy and the American Federal Experience (Bologna: Editrici Compositori), pp. 55-65.

(ed.) (2005a) Democracy and Federalism in the European Union and the United States. Exploring Post-National Governance (Abingdon: Routledge).

(2005b) 'Madison in Brussels: The EU and the US as Compound Democracies', European Political Science, 4 (2), pp. 188-98.

FONER, E. (1988) Reconstruction: America's Unifinished Revolution, 1863-1877 (New York: Harper and Row).

FORD, L. K. Jnr. (1994) 'Inventing the Concurrent Majority: Madison, Calhoun, and the Problem of Majoritarianism in American Political Thought', Journal of Southern History, 60 (1), pp. 19-58.

FORSYTH, M. (1981) Unions of States: The Theory and Practice of Confederation (Leicester: Leicester University Press). 
HAMILTON, A., Madison, J and Jay, J. (2003) The Federalist (Cambridge: Cambridge University Press).

HANF, D. (2001) 'Flexibility Clauses in the Founding Treaties, from Rome to Nice', in de Witte, B. et al. (eds), The Many Faces of Differentiation in EU Law (New York: Intersentia), pp. 3-26.

HERMANN, C. (2007) 'Much Ado about Pluto? The "Unity of the Legal Order of the European Union” Revisited', Working Paper, RSCAS 2007/05 (Florence, IT: European University Institute).

HIX, S. (forthcoming) What's Wrong with the European Union and How to Fix It (Oxford: Polity).

HOFSTADTER, R. (1955) The Age of Reform from Bryan to F.D.R (New York: Vintage).

HUNTINGTON, S. (1966) 'Political Modernization: America vs. Europe’, World Politics, 18 (3), pp. 378-414.

KELEMEN, D. (2007) 'Built to Last? The Durability of EU Federalism', in Meunier, S. and McNamara, K. (eds), Making History: European Integration and Institutional Change at Fifty (Oxford: Oxford University Press).

(2004) The Rules of Federalism: Institutions and Regulatory Politics in the EU and Beyond (Cambridge, MA: Harvard University Press).

KINCAID, J. (1999) 'Confederal Federalism and Citizen Representation in the European Union', in Brzinski, J. et al. (eds), Compounded Representation in Western Europe (London: Frank Cass), pp. 34-58.

KREPPEL, A. (2006) 'Understanding the European Parliament from a Federalist Perspective: The Legislatures of the United States and European Union Compared', in Menon, A. and Schain, M. (eds) Comparative Federalism: The European Union and the United States in Comparative Perspective (Oxford: Oxford University Press), pp. 245-71.

KYVIG, D. (1989) 'The Road Not Taken: FDR, The Supreme Court and Constitutional Amendment', Political Science Quarterly, 104 (3), pp. 463-81.

MAIR, P. (2007) 'Political Opposition and the European Union', Government and Opposition, 42 (1), pp. 1-17.

MAJONE, G. (2001) 'Two Logics of Delegation: Agency and Fiduciary Relations in EU Governance’, European Union Politics, 2 (1), pp. 103-22.

(2005) Dilemmas of Integration: The Ambiguities and Pitfalls of Integration by Stealth (Oxford: Oxford University Press).

MCDONALD, F. (2000) States' Rights and the Union: Imperium in Imperio, 1776-1876 (Lawrence: University of Kansas Press).

MCKAY, D. (2001) Designing Europe. Comparative Lessons from the Federal Experience (Oxford: Oxford University Press).

MENON, A. and Schain, M. (2006) Comparative Federalism: The European Union and the United States in Comparative Perspective (Oxford: Oxford University Press).

MORAVCSIK, A. (1998) The Choice for Europe: Social Purpose and State Power from Messina to Maastricht (Ithaca: Cornell University Press).

(2002) 'In Defence of the “Democratic Deficit”: Reassessing Legitimacy in the European Union', Journal of Common Market Studies, 40 (4), pp. 603-24.

(2005) ‘Europe Without Illusions: A Category Error’, Prospect, 112. 
LOUGHLIN, M. and Walker, N (eds) (2007) The Paradox of Constitutionalism: Constituent Power and Constitutional Form (Oxford: Oxford Universtiy Press).

LOWI, T. (2006) 'Eurofederalism: What Can European Union Learn from the United States', in Menon, A. and Schain, M. (eds) Comparative Federalism: The European Union and the United States in Comparative Perspective (Oxford: Oxford University Press), pp. 93-117.

NICOLAIDIS, K. and Howse, R. (eds) (2001) The Federal Vision: Legitimacy and Levels of Governance in the United States and the European Union (Oxford: Oxford University Press).

PISTONE, S. (1990) 'Altiero Spinelli and the Strategy for the United States of Europe', in Levi, L (ed.) Altiero Spinelli and Federalism in Europe and the World (Milan: Franco Angeli).

ROBERTSON, D. (2005) The Constitution and America's Destiny (Cambridge: Cambridge University Press).

SCHARPF, F. (2007) 'Reflections on Multilevel Legitimacy’, EUSA Review (Summer), pp. 2-11.

SCHMITTER, P. (2000) How to Democratize the European Union - And Why Bother? (Lanham: Rowman \& Littlefield).

SPINELLI, A. (1989) Una strategia per gli Stati Uniti d'Europa (Bologna: Il Mulino).

(1993) 'Il modello costituzionale americano e i tentavi di unità europea', in Albertini, M. (ed.), Il Federalismo: Anthologia e definizione (Bologna: Il Mulino).

STORING, H. (1985) The Anti-Federalist: An Abridgement (Chicago: University of

Chicago Press).

SWIFT, E. K. (1996) The Making of an American Senate: Reconstitutive Change in Congress, 17871841 (Ann Arbor: University of Michigan Press).

TRECHSEL, A. (2005) 'How to Federalize the EU ... and Why Bother', Journal of European Public Policy, 12 (3), pp. 401-18

WEILER, J. (1999) The Constitution of Europe (Cambridge: Cambridge University Press).

ZURN, M. (2000) 'Democratic Governance Beyond the Nation-State: The EU and Other International Institutions’, European Journal of International Relations, 6 (2), pp. 183-221.

Dr Andrew Glencross

European Union Democracy Observatory

Villa San Felice

Via dei Roccettini 9

San Domenico (FI)

I-50014

Email: Andrew.Glencross@eui.eu 